\title{
HERMENEUTIC DISTANCIATIONS IN POSTMODERN CHICANX LITERATURE: UTOPIAN AND DYSTOPIAN HORIZONS IN ANA CASTILLO'S SO FAR FROM GOD (1993) \& SALVADOR PLASCENCIA'S THE PEOPLE OF PAPER (2005)
}

\author{
Michael Grafals \\ Florida International University
}

\section{Abstract}

This essay focuses on the concept of distanciation in hermeneutic phenomenology and its relevance to an understanding of the utopian and dystopian dimensions in Ana Castillo's $S o$ Far From God (1993) and Salvador Plascencia's The People of Paper (2005), two postmodern novels that perceive Chicanx history aslant. I analyze how distanciations in these novels open possible cultural worlds that aid readers in interpreting new and/or estranging historical traditions. Ultimately, the distanciations in Ana Castillo's So Far From God pattern the hope for an emergent queer Chicanx spiritual-activist identity, while the distanciations in Salvador Plascencia's The People of Paper pattern a dystopic neoliberal worldview hidden behind decontextualzed kitchy representations of Chicanx identity. Although seemingly opposed, both cultural worldviews emerge through ruptures that occur between actual and possible worlds afforded by the novels' distanciations of Chicanx identities and histories.

Keywords: Postmodern Chicanx Literature, Distanciation, Estrangement, Hermeneutic Phenomenology, Utopia

DISTANCIAMIENTOS HERMENÉUTICOS EN LA LITERATURA CHICANA POSTMODERNA: HORIZONTES UTÓPICOS Y DISTÓPICOS EN SO FAR FROM GOD DE ANA CASTILLO (1993) \& THE PEOPLE OF PAPER DE SALVADOR PLASCENCIA (2005)

\section{RESUMEN}

Este ensayo se centra en el concepto de distanciamiento en la fenomenología hermenéutica y su relevancia para la comprensión de las dimensiones utópicas y distópicas en So Far From God (1993) de Ana Castillo y The People of Paper de Salvador Plascencia (2005), dos novelas postmodernas que perciben la historia Chicana oblicuamente. Analizo cómo los distanciamientos en estas novelas abren posibles mundos culturales que ayudan a los lectores a interpretar tradiciones históricas nuevas y/o extrañas. Los distanciamientos en So Far From God de Ana Castillo modelan la esperanza de una identidad Chicana espiritual, activista, queer y emergente, mientras que los distanciamientos en The People of Paper de Salvador Plascencia modelan una cosmovisión neoliberal distópica escondida detrás de representaciones kitsch que descontextualizan la identidad Chicana. Aunque aparentemente opuestas, ambas visiones del mundo cultural emergen a través de rupturas que ocurren entre mundos reales y posibles que ofrecen los distanciamientos de las identidades e historias Chicanas en las novelas.

PAlabras Clave: literatura chicana postmoderna, distanciamiento, extrańamiento, fenomenología hermenéutica, utopía.

DOI: https://doi.org/10.25145/j.recaesin.2020.81.10

Revista Canaria de Estudios Ingleses, 81; November 2020, pp. 153-168; ISSN: e-2530-8335 
In Toni Morrison's essay "The Sources of Self-Regard”, she describes her disappointment on reading letters from a high school class on their thoughts of Beloved. She felt that they did not "question the history," that they failed to "analyze it or confront it in some manner that is at odds with the historian or even the novelist's version of it": "One sort of takes it, swallows it, agrees with it. Nothing is aslant. Although in fact, the reason I had written the book was to enter into that historical period from some point of view that was entirely different from standard history" (Morrison 306). The terms of Morrison's critique are relevant to the narrative and reading strategies solicited by postmodern fictions. The goal in writing Beloved was to enter history from a specific "point of view" that perceives history "aslant." These special slanted forms of perception are both implicit in the text and encouraged as a reading practice. This perception corresponds to the concept of distanciation in hermeneutic phenomenology. Distanciation refers to a suspension of our immersion in an actual world and an opening up to a world that the text proposes as possible (MacAvoy 15). This essay analyzes the different social and historical horizons these "slanted" forms of distanciation can take in postmodern Chicanx fictions, looking especially at Ana Castillo's So Far From God (1993) and Salvador Plascencia's The People of Paper (2005). Ultimately, the distanciations in Ana Castillo's So Far From God pattern the hope for an emergent queer Chicanx spiritual-activist identity, while the distanciations in Salvador Plascencia's The People of Paper pattern a dystopic neoliberal worldview hidden behind kitchy and decontextualzing representations of Chicanx identity. Although seemingly opposed, both cultural worldviews emerge through ruptures that occur between actual and possible worlds afforded by the novels' distanciations of Chicanx identities and histories.

Although the concept of distanciation refers to the hermeneutics of HansGeorg Gadamer and Paul Ricoeur, the sense of the idea is already operative in the writings of Chicanx postmodern cultural theorists like Gloria Anzaldúa, Emma Pérez and Chela Sandoval. Anzaldúa conceptualizes her aesthetic vision as the need to experience "a radical shift in perception, otra forma de ver" (Light/Luz 16) and Emma Pérez describes the "decolonial imaginary" as surviving in colonialist historiography as "a faint outline gliding against a wall or an object" (Pérez 7). Distanciations resonate with Chicanx decolonial strategies that work within and against hegemonic historical narratives. Although there is much to critique in Gadamer's notion that the goal of interpreting distanciation is to better belong to a tradition (Truth and Method 293), I reorient this understanding of tradition through Stuart Hall's conception of articulation, which sees cultural identity as "the different ways we are positioned by, and position ourselves within, the narratives of the past" ("Diaspora" 225). Within the hermeneutic play of perceptual positions that we find in Ana Castillo's So Far From God and Salvador Plascencia's The People of Paper, we can then take a fresh look at the hermeneutics implied by Gloria Anzaldúa's "mestiza way": "Pero es difícil differentiating between lo heredado, lo adquirido, lo impuesto. She puts history through a sieve, winnows out the lies, looks at the forces that we as a race, as women, have been part of. Luego bota lo que no vale, los desmientos, los desencuentros, el embrutecimiento" (her emphasis, Borderlands 104). 
This archeological metaphor distanciates a reading process that strives to discover utopian and/or dystopian dimensions in a text.

Distanciation is Paul Ricoeur's translation of the German word Verfremdung which can refer, according to Ernst Bloch's metaphor, to a "distancing mirror above the only too familiar reality" ("Entfremdung" 125). Bloch's metaphor will be useful for our purposes since the experience of a distanciating distance, experienced by our novels' protagonists, open gaps in their ordinary perceptions of reality. While Verfremdung is often translated as distanciation, the term bears the trace of other concepts, that is, both alienation and estrangement are considered by some scholars to indicate the essence of "literariness". For instance, Russian formalist Viktor Shklovsky called Ostranenie (or "making-strange") the way writers "give back the sensation of life, in order to make us feel things". For Shklovsky, estrangement leads to the "complication of the form, which increases the duration and complexity of perception" (Shklovsky 80). Shklovsky opposes this artful strangeness to "automatization," a form of perception that objectifies reality, converting it into a formula or stereotype. Shklovsky direly warns his readers: "This is how life becomes nothing and disappears. Automatization eats things, clothes, furniture, your wife and the fear of war" (ibid). With this opposition, Shklovsky reflects the tension in our novels between a dystopic vision that commodifies and exploits reality and one that disrupts objectification through creative distanciations. Similarly, in Ato Quayson's definition of postcolonial literature, he notes the importance of "perspectival alienations" that "alienate the referent from itself, and ultimately lead to a new view of society that moves beyond the existent, here defined as the dominant of social and political relations" (Quayson 94). Quayson's definition is important because it points to the way perspectival alienations help "discompose and reconstitute political reality” (ibid). What Quayson adds to Shklovsky's conception of estrangement is the way these estrangements or alienations intimate forms of political experience.

Hermeneutic phenomenology studies these moments of distanciation or estrangement of an ordinary or first-order of reality. In the analysis of novels, hermeneutics then traces the significance of these distantiations within the contexts of the narrative and its implied historical horizon. The moment of distanciation and the configuration of these moments in narrative (implicit both in the text and in the mind of the reader) would be understood as opening an invisible light or horizon on the world. Distanciation here relates to the concept of the epoché, central in phenomenology, which for Paul Ricoeur, contributes to perceptions that suspend ordinary reference and project new possibilities ("Metaphorical Process" 153). The epoché or distanciation (Ricoeur innovatively blends these conceptions together in his writings) have both negative and positive movements. As Ricoeur hyperbolically suggests, "the role of most of our literature is, it seems, to destroy the world" while also providing a world that it "unfolds, discovers, reveals" (Hermeneutics 103; 106).

A brilliant example of distanciation is the malogra in Ana Castillo's So Far From God. In the novel the malogra is a mythic creature that attacks the character Caridad. The amorphous quality of the being brings out important metaphoric implications: 
A thing that might be described as made of sharp metal and splintered wood, of limestone, gold, and brittle parchment. It held the weight of a continent and was indelible as ink, centuries old and yet as strong as a young wolf. It had no shape and was darker than the dark night, and mostly, as Caridad would never ever forget, it was pure force. $(S F G 77)^{1}$

Although this description mystifies our perception of the creature, it can be read as envisioning an attack by a colonial-patriarchal power as a structural-historical force operative in history, considering the reference to "parchment" and "ink" (and thus to writing and the law) and its possible reference to a ship of "sharp metal and splintered wood" and other exploitable resources. Estranging the description envisions a deeper historical reality obfuscated by ordinary reality. Plascencia's The People of Paper uses distanciation differently, often gesturing to more shallow realities as a means of playfully engaging with Chicanx literary and historical traditions.

Plascencia's narrator deliberately entraps readers into his dystopian neoliberal horizon of the world but he also gives them the literary resources to escape his imaginary. Part of the interpretation game of reading The People of Paper is outsmarting Plascencia's kitschy illusions. Plascencia, as a character in his own novel, has a girlfriend named Cameroon who has the habit of pressing the stingers of honeybees into her body. The fever from the stings gives off a saintly halo and she is frequently described as removing "thorns" from her body. When asked why she has this habit, she says that "when one is sad there is only insects or sex" (Plascencia 128). This bizarre distanciation appears to idealize through "nature" and religious imagery an ordinary drug addiction. Although this may make it seem like a more superficial distanciation from Castillo's passage, this perception builds on a configuration of others that skillfully intimate the Plasencia-character's broader pessimistic horizon of representation for the "ethnic fiction" writer, whose role in the publishing industry seemingly is to provide commodifiable images of ethnic suffering, or more specially the private pleasure-in-pain the novel calls "sadness", a feeling that resonates with a discourse on "soledad" in Latin American literary traditions that Plascencia engages with in his allusions to Octavio Paz's El laberinto de la soledad (1950) and Gabriel García Márquez's Cien años de soledad (1967). Plascencia's representation of soledad resonates with the idea of jouissance in psychoanalysis, which terms a pleasure-inpain for a lost fantasy object.

As intimated, the concept of distanciation resonates with a host of concepts that includes terms like alienation, estrangement and enchantment. The concept(s) can resonate with negative experiences of alienation, as described for instance by Karl Marx's description of estranged labor or in Franz Fanon's description of racial interpellation in Black Skin, White Mask. Or it can resonate with positive moments of enchantment, as explored for instance in nature poems (for instance of the pastoral lyric tradition, implicit in early passages of Plascencia's novel). As with

\footnotetext{
${ }^{1}$ From here on out, I will use $S F G$ to indicate So Far from God.
} 
the examples of the malogra or Cameroon's bees, distanciation can move within a spectrum that accounts for alienating or enchanting experiences, moments that heighten and complicate perception. Ernst Bloch in his article "Entfremdung, Verfremdung: Alienation, Estrangement" makes a distinction between evil alienation and beneficent estrangement, which will be crucial when we examine our two novels. Evil alienation corresponds to a perception of human life as one dominated by the rule of commodification and exploitation: "Everything becomes a commodity. All objects and people turn into goods for sale. Relationships between people are reduced to their exchange value, while the circulation of commodities becomes an independent force behind the backs and above the heads of human beings" ("Entfremdung" 122). In contrast for Ernst Bloch, there is a positive strangeness "that does not betray and sell us" and that lets us "contemplate experience separated, as in a frame, or heightened, as on a pedestal" (ibid 122). The affects this beneficent estrangement inspires are "amazement and concern" (125).

Bloch's descriptions are helpful because they echo the implicit concerns of both Castillo and Plascencia about the dangers of commodification as maleficent forms of human objectification and literary perception. Yet postmodern literary strategies complicate Bloch's neat binary of a negative alienation versus a positive estrangement. Postmodern literature often offers a heightened and nuanced awareness of the effects of commodification on everyday perception, but they often use deliberate deception to trick readers into identifying with characters, images and plot sequences that reduce human characters to simplified abstractions and that falsify history into stereotypical ideological myths. This is especially true of the sly awareness of commodification in Plascencia's novel. Commodification also complicates representation in Castillo's So Far From God. The novel concludes with the legacy of the novel's deceased sisters coming to a ruin as their mother Sofia becomes the "presidenta" of the organization "MOMAS, Mothers of Martyrs and Saints", a cross between the Vatican and Disney World. The novel ends with a lengthy description of "useless products and souvenirs" and tacky rituals used to honor the dead sisters that the novel has been trying to triangulate into a utopic pattern of emergent Chicanx female identity. Both novels deploy the postmodern literary strategy of resisting narrative closure. This allows the novels to create the kind of open fiction envisioned by Anzaldúa, one that "questions its own formalizing and ordering attempts, its own strategies, the machinations of thought itself" (Light/ Luz 7). By undoing closure these novels encourage what the narrator of So Far From God calls "connect-the-dots game" (120), a critical reflexive turn on the reader's part to discover what corresponds to Ricoeur's conception of the "dimension of reality that is signified by the plot" (Figuring 58). This dimension is what is known in hermeneutics as the "horizon" proposed by a work of art, which for Hans-Georg Gadamer "takes place in the work of art itself in such a fashion that at the same time it is sustained in an abiding" (Ways 104).

For Ricoeur, this dimension intimated by the plot "exposes" readers (this metaphor echoes an ethical encounter) to what he terms an "enlarged self" which can be linked to Ernst Bloch's concept of "anticipatory illumination". Ricoeur describes this hermeneutic encounter thus: "It is not a question of imposing upon the text our 
finite capacity of understanding, but of exposing ourselves to the text and receiving from it an enlarged self, which would be the proposed existence corresponding in the most suitable way to the world proposed" (Hermeneutics 106, my emphasis). In Ricoeur's hermeneutics, this exposure to an enlarged self echoes an existential process of the subject coming into a new awareness of self through an experience of distanciation: "it must be said that the subjectivity of the reader comes to itself only insofar as it is placed in suspense, unrealised, potentialised" (ibid). This experience is prominent in first-person narratives in Latinx literature, where we often find characters feeling intense existential moments of distanciation that echoes this hermeneutic process of the self becoming suspended. For instance, in Piri Thomas' Nuyorican memoir Down These Mean Streets (1967) the protagonist's moment of selfdistanciation comes as he becomes radically aware of his own toxic masculinity, his previous mode-of-being. This event is described as feeling as "though I had found a hole in my face and out of it were pouring all the different masks that my carapalo face had fought so hard to keep hidden" (Thomas 321). Similarly, in the recent Miami Bildungsroman by Jennine Capó Crucet, Make Your Home Among Strangers (2015), the Cuban-American protagonist comes home to Miami after living for a semester in a predominantly white university in the Northeast and she describes her feeling of alienation on seeing her mother, in a moment of distanciation that has class and ethnic implications:

But spotting her before she saw me in the terminal-in that fake gold outfit, her face oily, her hands fidgeting with the rings on her fingers-had made my stomach turn, and I just wanted to be alone somewhere to catch my breath, to have a minute to sync up my idea of home with reality" (Capó Crucet 139).

Both moments in these first-person narratives entail processing different understandings of reality, moments that Gloria Anzaldúa theorized as the experience of nepantla. These expressions of self-distanciation in Latinx subjects echo the textual effect of distanciation in Ricoeur's description of literary discourse: "The strategy of this discourse involves holding two moments in equilibrium: suspending the reference of ordinary language and releasing a second order reference, which is another name for what we have designated above as the world opened up by the work" (Hermeneutics 54). But while the existential distanciations above relied on depictions of first-person experiences, a distanciation of a character's identity can also occur implicitly in the structure of the text by means of the "new dimension of reality that is signified by the plot" (Figuring 58).

This is the case of the configuration of characters in Castillo's So Far From God. The novel takes place in the New Mexican town of Tomé and concerns the separate yet shared lives of four sisters in a working-class family headed by their mother Sofia. The four sisters are Esperanza, Caridad, Fe and La Loca (which translates to Hope, Love/Charity, Faith, and Crazy), names referencing what are known as the theological virtues in Paul the Apostle's First Epistle to the Corinthians: "At present we see indistinctly, as in a mirror, but then face to face. At present I know partially; then I shall know fully, as I am fully known. So faith, hope, love remain, 
these three; but the greatest of these is love" (New American Bible 592). The biblical allusion and the metaphor of the mirror suggests a configuration of characters, as if they mirrored each other. After Caridad recovers from her attack by the malogra, she discovers she has healing powers and decides to become a curandera, or folk healer. The narrator (unnamed, but who often adopts the tone of a neighborly chismosa or gossiper) describes a moment of Caridad realizing her renewed identity, alluding to the passage from Corinthians: "Caridad had always been charitable. She had faith and hope. Soon, she would have wisdom from which she had sprung, and sooner still her own healing gifts would be revealed" (56). The novel reconfigures Paul's virtues, now adding wisdom (sophia in Greek), also a reference to her mother Sofia. The reference to both the virtues and the characters urges us to think conceptually about the characters as a configuration of beings.

The passage clues readers into ways of engaging the characters in what Edmund Husserl would call the "imaginative variations" experienced in an epoché: a hermeneutic epoché or distanciation allows one to meditate on exemplary figures (like the sisters) and vary their features in order to "imaginatively produce other possibilities" (MacAvoy 21). In the novel's plotting of characters, the sisters form what José Esteban Muñoz calls (in his reflections on Ernst Bloch's hermeneutics in The Principle of Hope) "blueprints and schemata of a forward-dawning futurity" (Muñoz 1). A description of the sisters can help intimate what Ernst Bloch calls the "anticipatory illumination" of the text:

The anticipatory illumination of a work of art is an image, a constellation, a configuration which is closely tied to the concrete utopias in reality that are lit up on the frontal margins of reality illuminating the possibilities for rearranging social and political relations so they engender Heimat, Bloch's symbolic term for the home that we have all sensed but none have ever experienced or known. (Zipes 32)

A description of the characters may help intimate these anticipatory illuminations. There is the oldest Esperanza, the more pragmatic and politically conscious of the sisters and "the only one to get through college" (SFG 25). Her leadership in student protests lead to the introduction of the first Chicano Studies classes offered in the curriculum (239). She becomes an "ace reporter" and advances in her career, soon leaving New Mexico to broaden "her horizons" and free "herself from the provincialism of her upbringing" (35). She is sent on an assignment to the Middle East where she is taken hostage and dies (although she sometimes returns "ecoplasmically" to inspire the political consciousness of her mother and younger sister La Loca) (186). Fe is the sister most critiqued by the narrator. She is described as "since birth [acting] like she had come as a direct descendent of Queen Isabella" (157), "light-skinned" (157) and desiring "a life like people do on TV" (189): "with her own hard-earned money from all the bonuses she earned at her new job" she is described as finally getting "the long-dreamed-of automatic dishwasher, microwave, Cuisinart, and the VCR" (171). Her name ironically suggests a faith in material success and she suffers for this: striving on "moving up quick at Acme International," she dies from cancer cleaning chemicals from high-tech weapons (178). When she 
dies the narrator plainly asserts that she has no chance of returning as a spirit like the other sisters: "Fe just died. And when someone dies that plain dead, it is hard to talk about" (186). The youngest sister La Loca appears to be loosely based on the Belgium Saint Christina the Astonishing: when at three years of age La Loca (her family forgets her original name) dies, visiting hell, purgatory and heaven, she returns to life at her own funeral, suddenly becoming "repulsed by the smell of humans" (23) and living out the rest of her days as a hermit in her family home, where she has visions and receives paranormal visits from spectral apparitions like la Llorona and from a mysterious "Lady in Blue" that comforts her as she inexplicably dies from AIDS (244).

Yet much of the novel's focus is on Caridad who undergoes an initiation process as a curandera under her landlady Doña Felicia. When Caridad and Doña Felicia visit the pilgrimage site of Chimayó, she catches a fleeting sight of Esmeralda and her presence inexplicably so overwhelms Caridad that she falls into a spiritual meditative state that sends her to live a year alone in the Sangre de Cristo mountains. When she finishes her year-long spiritual retreat, she soon discovers Esmeralda, but their relationship is cut short by the overzealous Francisco el Penitente, who stalks the couple up a mountain where they leap or are taken-in by Tsichtinako, a goddess of the Acoma Pueblo Indians who guides "the two women back, not out toward the sun's rays or up to the clouds but down, deep within the soft, moist dark earth where Esmeralda and Claridad would be safe and live forever" (211). The lives of the sisters are all cut short too soon, and although this lends a fragmentary quality to the novel the implication is that (apart from Fe, who has no spiritual rebirth) the sisters have become saints or martyrs that the reader needs to understand as a configuration. Although there is an ironic effort at official canonization when their mother Sofía creates the institution of the "MOMAS Mothers of Martyrs and Saints," the meaning of the "saints" are never fully clear. Devotees for instance never figure out the spiritual purpose of La Loca after death: "She was not particularly noted for answering the pleas of the desperate and the hopeless, neither, like el Saint Jude, for example, who is the patron saint of los desesperados. In other words, people never really could figure out who La Loca protected and oversaw as a rule, or what she was good to pray to about" (248).

Yet there are various passages when the narrator gives a metacommentary on the novel, leading us to believe there is a purposeful design to the sisterly configuration. The novel articulates a metacommentary in a digressive chapter, a fragmented narrative of María and Helena, a couple on a road trip going to "where María's ancestors had been buried for the last nine generations-until her father had left New Mexico to try his luck in California, where indeed, he had done well with a string of taquerías in East LA" (SFG 122). They find themselves stalked by a mysterious male driver (echoing what will happen later with Esmeralda and Caridad). The narrator asks the reader for patience: "Now, neither the woman nor her companion in this account was Caridad's Woman-on-the-wall in Chimayó, but with some patience (a virtue no one could ever have too much of) a few people actually made the connection in the end" (120). The title of the chapter, a sly nod to the kind of chapter titles found in Cervantes or García Márquez, states: "What 
Appears to Be a Deviation of Our Story but Wherein, with Some Patience, the Reader Will Discover That There is Always More Than the Eye Can See to Any Account" (120). She says this fragment is like "one of those connect-the-dots games" (120) and that it will be about "all kinds of beginnings and endings but mostly, like all accounts, about what goes on in the middle" (124). This metacommentary alludes to what Ricoeur calls, in his work on narrative theology, an "art of emplotment" that "provides then heterogenous elements with the ambiguous status of a concordantdiscordant whole" (Figuring 239). Although the meaning of the mother-sisters configuration cannot be explicated straightforwardly, if we analyze the ways the sacred becomes distanciated we can uncover the outlines of a spirituality that is activist, queer and historically and ecologically conscious.

In Chicanx narratives, religion and spirituality often provide contested positions for negotiating actual and possible cultural worlds. This is especially true of postmodern Chicanx novels, whose parodic and intertextual articulations of the religious and the spiritual work to position these into new configurations. The religious and the spiritual provide important archives of meaning for the unfolding of a Chicanx identity, for as Theresa Delgadillo states, spirituality in Latinx narrative offers important linkages between racial, ethnic, national, gender and sexual identities (Delgadillo 240). Though postmodern Chicanx narratives often approach religion and spirituality in a skeptical and playfully irreverent way, nonetheless their intricate understandings of the sacred aid in what David Vázquez terms narrative triangulation, or the "dynamic technique that engages multiple way points, distances, and recalculations in the process of navigation" (Vázquez 3). Ana Castillo and Salvador Plascencia distanciate the religious and spiritual in order to project specific and/or emergent ways of belonging in Chicanx cultural worlds.

For instance, a new queer projection of the spiritual operates in Caridad's retreat to the cave in the Sangre de Cristo mountains. The retreat combines spirituality, queer desire, and a reverence for the natural world that anticipates Nicole Seymour's thesis in Strange Natures (2013) that there is an implicit "tradition of queer environmentalism" that links "the queer to the natural world" (1). The narrator reveals Caridad's spiritual point-of-reference during the retreat: "she did not think of time or of no one, not Doña Felicia, not her mom or the other members of her family, not even herself, but not a sleeping or waking moment went by when her heart did not long for Woman-on-the-wall in Chimayó" (SFG 89). Yet a paragraph before this we see how this love emanates outward towards the natural world: "she woke to a delicate scar in the horizon that gradually bled into day and saw the sun then raise itself like a king from its throne over the distant peaks, Caridad only knew that she wanted to stay there and be the lone witness to that miracle every dawn" (ibid). The metaphor of the scar on the horizon bleeding into day evokes the linkage that is being established between inner desire and natural reality. When she is discovered near the time of Holy Week, hundreds of Catholics (who went "instead of going to Mass at their local parishes") (87) and Indigenous people from the pueblos, "made their way up the mountain to la Caridad's cave in hopes of obtaining her blessing and just as many with hopes of being cured of some ailment or another" (SFG 87). 
Although she remains silent and immobile in her encounters with visitors, some believe her to be "the ghost of Lozen, Warm Springs Apache mystic woman warrior" (88) while Francisco el Penitente looks on her "as one looked upon Mary," as "all that was chaste and humble" (192). These conflicts of interpretation reveal what Ricoeur terms "the opposition between alienating distanciation and belonging" (Hermeneutics 93). In other words, we see a tension between a foreign horizon of being and two traditions (Catholic and Indigenous) attempting to appropriate this distanciation. Castillo positions Caridad's queer spirituality as aslant of these two traditions. This narrative strategy is linked to Castillo's attempt to situate an emergent identity in-between traditions. Castillo is explicit about this strategy in Massacre of the Dreamers: "Creating some distance from the last generation allowed such guerrilleras to adapt a spirituality to their own needs while still operating within their culture" (Massacre 166-167).

With its configuration of sisters, Castillo's novel imagines what Ernst Bloch would term a concrete utopia which is "relational to historically situated struggles [and] a collectivity that is actualized or potential" as opposed to "abstract utopias" which are "are untethered from any historical consciousness" (Muñoz 3). Apart from $\mathrm{Fe}$, the spiritualities of Sofia and her daughters are deeply grounded in material and social realities. This thematic aspect of the text culminates in a syncretic Good Friday procession of the cross, a seemingly spontaneous religious event in the novel that unites both Christians and Indigenous religions. As a figure of Jesus goes through the stages of the cross, the crowd gives testimony on the effects of environmental violence on their community. For example, one indigenous woman proclaims: "Our people have always known about the interconnectedness of things; and the responsibility we have to 'Our Mother,' and to seven generations after our own. But we, as a people, are being eliminated from the ecosystem, too...like the dolphins, like the eagle" (SFG 242). This juxtapositioning of environmental justice and syncretic religious ritual is implicitly contrasted with Francisco el Penitente's vision of faith as articulated earlier in the novel, which obfuscates historical reality in favor of a vision of heaven uncaring of a broader historical or natural reality.

When Francisco is six, all the boys at his school are vaccinated for smallpox, but not his mother and sister, who soon die of the disease. Francisco's idea of his mother soon becomes otherworldly: "as the years went on his mother ever ascending toward heaven became more remote as a former human being and more akin to a celestial entity" (97-98). Francisco imagines his mother affectionately as "una santita en el cielo watching over" her family (98). This distanciation begins to have an effect on Francisco's horizon of being when he becomes a santero (in this context, a maker of "bultos" or "wooden sculptures of saints") (96). Francisco believes he channels the divine essence of the saints when he crafts their images. But as he forms statues of St. Francis of Assisi, the essence he imagines is far removed from the actual earthly life of the Saint:

St. Francis himself could only guide Francisco's hand since it wasn't St. Francis the holy man whom Francisco was imagining, the one who had cared for the poor, the infirm and the hungry, the orphaned children and all the innocent creatures on 
earth, but St. Francis in his rightful eternal place in heaven, from which privileged place he was able to work miracles for the all-too-human beings left on earth. (101)

The chapter soon reiterates this tension between material and celestial reality in its description of Francisco's apprenticeship with his uncle: "[they] labored with the natural elements, sun, air, and earth and prayed all the while as they worked together in silence-like their Spanish ancestors had done for nearly three hundred years on that strange land they felt was so far from God" (101-102). Both passages above reveal an ambiguity within religious tradition(s). In both instances, although Francisco labors with materials evoking deep connections to the natural world (as St. Francis and the "natural elements" imply), yet the horizon of being that ultimately emerges from his work, his specific distanciation of the world, imagines the celestial as radically separate and uncaring of socio-historical and ecological realities.

So far we have seen how distanciations in Castillo's novel involve readers into different perceptions of seeing the world, often implying a imagined composite identity that is socially-conscious, queer, spiritual and earth-bound and that emerges within and against competing traditions. For instance, Caridad's spiritual retreat to the Sangre de Cristo mountains involves a play of horizons. We get her spiritual perception and connection to the natural world inspired by her sighting of Esmeralda, but just for a brief paragraph. We are then faced with a variety of perspectives attempting to articulate Caridad within a tradition, as we lose sight of her perception within conflicting articulations. And as a configuration of characters, the mother and sisters provide variations of what Ricoeur terms the "enlarged self" (Hermeneutics 106), or what Ernst Bloch conceptualized as an "anticipatory illumination" of an emergent identity. Finally, we saw how Francisco el Penitente is crucial for the further illumination of the novel's Chicanx horizon. As Ricoeur states, "it is only in a conflict of rival hermeneutics that we perceive something of the being to be interpreted" ("Existence" 19). Francisco's devaluation of the "all-too-human" world for a celestial world conflicts with the significance of the Good Friday procession and the spiritualities of Caridad and even Esperanza who (although generally skeptical of the supernatural while alive) still prays "to Grandmother Earth and Grandmother Sky" (SFG 38). But for Salvador Plascencia's The People of Paper, the distanciations do not ultimately reveal a utopic horizon; rather, its kitschy and sentimental representations demonstrate (albeit ironically) an escape from socio-historical and ecological realities and a movement towards a Chicanx neoliberal individualism that enjoys its culture melancholically. David Vázquez's study of narrative triangulation in Latinx literature finds that its authors are "committed to countering liberal individualism as a primary aspect of their antiracist strategies" (Vázquez 23). Although on the surface Plascencia's novel promotes a racist and sexist neoliberal worldview, in an ironic way Plascencia's novel is attempting indirectly a similar strategy by encouraging its readers to negate its own radically dystopian cultural horizon.

In The Plague of Fantasies, Slavoj Žižek states that art is "fragmentary, even when it is an organic Whole, since it always relies on the distance towards fantasy" (Žižek 25). Fantasy in psychoanalysis refers to an illusion of a consistent, unified and desired reality that is generated to obfuscate and/or reveal an inconsistency 
or antagonism within social-material reality. While Castillo's novel proposed a desired futurity, it does so in a fragmented way that takes into account competing traditions of interpretation, thus allowing a futurity to gleam between the lines. This is not the case with Plascencia's novel because there is a parodic postmodern shallowness or flatness at work in his novel that solicits our curiosity and critique. Although Žižek claims that "melodrama and kitsch are much closer to fantasy than 'true art' " (ibid 26), Plascencia parodies these modes as decontextualizing myths that readers should critique (unlike Castillo, there is no utopic alternative in the novel). As distanciations, the novel's illusions do not intervene to illuminate history in a new utopic way; rather, realities are parodically flattened and decontextualized into what Bloch terms abstract utopias. This is the case of Federico de la $\mathrm{Fe}$, one of Plascencia's several stereotypes of the Mexican migrant to Los Angeles.

Federico's origins are hyperbolically pastoral: by the river Las Tortugas, Federico chases "goats and sheep to bring [his daughter] milk" (Plascencia 19) and when we first meet him he is carrying his "conjugal mattress past the citrus orchard" and towards the river to clean out the urine from the mattress he shares with his wife Merced and daughter Little Merced (18). A chronic bedwetter, Federico refuses to wear diapers "like the ones their daughter wore" (ibid). Both "child and husband" are described as sleeping in the nude "curled around Merced" (ibid). When Merced leaves, because she is fed up with being pissed on (or as she says "A wife can only take so many years of being pissed on") (18) this begins his "sadness" and the sensation of the "weight of a distant force looking down on him" (18) that he comes to believe is the presence of the planet Saturn, which turns out to be Plascencia the author. Federico realizes that the only cure to "the sadness" is what he calls "burn collection," which involves the infliction of constellations of burn marks on the body (187). The infliction of pain on the body becomes a repeated motif in the novel: for instance, Little Merced obsessively sucks on limes to feel pain (she later dies of "citric poisoning" only to be resurrected by a curandero) and Plascencia's girlfriend Cameroon seeks solace from being abandoned by her father by keeping a Mason jar full of bees that she uses to sting herself. The painful nostalgia for a lost past is described as a foundational "sadness" that is supposed to add a sense of depth to the emotional life of the characters. But what the novel is trying to promote in Federico de la Fe as a "biblical" sadness is mere infantile fantasy (128). This fantasy leads to a distortion of history, turning Mexico into a primitive Eden, a place built on "mud" and not cement like Los Angeles (as the novel repeatedly mentions).

The novel becomes an amalgamation of various genres and narratives of Chicanx literary and historical traditions, including the magical realist novel, the history of social protests, and narratives of migration, gang life, and drug abuse. But it distanciates these traditions, especially the history of protest movements. Federico and Little Merced migrate to the city of El Monte in Los Angeles where he works picking flowers with the Chicanx flower-picking gang "EMF" (El Monte Flores). It is a gang "not like city gangs": "They did not loot fruit stores or steal car parts; they just drank mescal and worked in the furrows harvesting flowers" (34). Apart from the "brinca" initiation ritual, they are described as mostly passively sitting "around the dominoes table drinking mescal and chewing rose petals" (38). 
Federico soon enlists the gang to embark on a war on Saturn, in what he terms "a war of volition and against the commodification of sadness" (53). Federico tells the gang: "We are being listened to and watched, our lives sold as entertainment. But if we fight we might be able to gain control, to shield ourselves and live our lives for ourselves" (ibid). As part of the novel's decontextualization strategies, the gang agrees with no mention being given of either debate or deliberation, or evidence of Saturn's celestial control over their lives. Like the pastoral representation of Las Tortugas, El Monte is a kitschy abstraction of social reality, where no mention is made of structural inequality or exploitation. The goals of the war appear to be "dignity through privacy" and the "right to be unseen" (46), demands that estrange "representation" as a concept that means the depiction of identity and the political act of standing in for something.

There is a telling moment near the end of the novel when the gang rouses the city of El Monte to come outside and say "all the things we had always wanted to say, letting the words float" (209). The novel's pages are divided into different sections, sometimes multiple columns, according to different characters, but in this sequence each page is chaotically filled with five or more sections, some passages even printed sideways. As the book becomes cluttered with different voices and columns, we read the voice of a minor character Little Oso. As he tries to freely write down what is on his mind, he realizes the limitations of his mental horizon: "I didn't know what else to say. This is my home, this town of furrows and carnations, and I don't care where our flowers go, if they are sniffed by royalty or movie stars. Whatever happens beyond our borders is not my worry, it is only Monte and its sky that I care about" (215). This myopic social perception connects with a series of other distanciations. For instance, Federico discovers on his way to Los Angeles a Tijuana mechanic who specializes in mechanical tortoises. By entering the lead of their shells, Federico is able to shelter his thoughts from Saturn's penetrating gaze (we are even given a glimpse of Saturn's perception, as half the page is filled with binary numbers) (97). The image of Federico crawling into the safety of the shell, and the reference to turtles (his hometown was called "Las Tortugas," The Turtles in English) refers to Federico's infantile fantasies at the start of the novel. Plascencia may be playfully echoing Octavio Paz's critique of "the Mexican macho" who is described as "a hermetic being, closed up in himself" (Paz 31). Plascencia as Saturn also lacks broader social or ecological horizons. When the gang uses the lead of the turtle shells to cover their homes (though they eventually suffer from lead poisoning), Saturn is forced to contemplate nature:

Not all is about gangs and a sad man who wets his bed. There is time and space for everything, to observe the thousands of tragedies of a single growing season. To watch the flower stalks burst through the soil, interweaving their roots with the neighboring plant, tangling their wires under the privacy of soil, tightly gripping, gradually pulling themselves to each other to feel the brush of leaves against the stems. (92)

Saturn or Plascencia soon after develops a writer's block and the novel is interrupted to shift its focus for several chapters on Plascencia's family and 
relationship with Cameroon. The passage above is remarkable as it describes in terms of vegetation a brief desire for interconnectivity and intimacy that challenges Federico's melancholic desire for privacy.

To conclude, Plascencia's distanciations parodically flatten our perceptions of Chicanx identity and history to make us more keenly aware of what Shklovsky termed "automatization," a form of perception that commodifies reality and converts it into mere formula or stereotype. The postmodern novel in this mode encourages a critique of commodification as forms of dystopian perception. Ana Castillo's So Far From God is more utopian in its aims. It offers what Chela Sandoval describes in Methodology of the Oppressed as a "hope that a new subject of history can rise from the rubble of the old order to forge another, more liberatory" one (Sandoval 15). This utopic hope survives in the novel like Emma Pérez's "faint outline," intimating a decolonial imaginary gleaming just beyond our horizons (Pérez 7).

REVIEWS SENT TO AUTHOR: 29-6-2020; REVISED PAPER ACCEPTED FOR PUBLICATION: 14-9-2020 


\section{WORKS CITED}

Anzaldúa, Gloria. Borderlands/La Frontera: The New Mestiza. Fourth Edition ed., Aunt Lute Books, 2012.

Anzaldúa, Gloria. Light in the Dark/Luz En Lo Oscuro: Rewriting Identity, Spirituality, Reality. Ed. Ana Louise Keating, Duke University Press, 2015.

BLOCH, Ernst. "Entfremdung, Verfremdung: Alienation, Estrangement." The Drama Review: TDR. (Transl. Anne Halley \& Darko Suvin) 15/1 (1970): 120-125.

Castillo, Ana. Massacre of the Dreamers: Essays on Xicanisma. University of New Mexico Press, 2014. Castillo, Ana. So Far from God. Norton, 2005.

Crucet, Jennine Capó. Make Your Home among Strangers. Picador, 2016.

Delgadillo, Theresa. "Spirituality.” Routledge Companion to Latinola Literature. Ed. Suzanne Bost \& Frances R. Aparicio, Routledge, 2013. 240-250.

Gadamer, Hans-Georg. Heidegger's Ways. Translated by John W. Stanley, State University of New York Press, 1994.

Gadamer, Hans-Georg. Truth and Method. Transl. Joel Weinsheimer \& Donald G. Marshall, Continuum, 2006.

Hall, Stuart. "Cultural Identity and Diaspora." Identity: Community, Culture, Difference. Edited by Jonathan Rutherford. Lawrence \& Wishart, 1990. 227-237.

MacAvor, Leslie. "Distanciation and Epoché: The Influence of Husserl on Ricoeur's Hermeneutics." Hermeneutics and Phenomenology in Paul Ricoeur: Between Text and Phenomenon. Ed. Scott Davidson \& Vallée Marc-Antoine. Springer, 2016. 13-30.

Morrison, Toni. The Source of Self-Regard: Selected Essays, Speeches, and Meditations. Alfred A. Knopf, 2019.

Muñoz, José Esteban. Cruising Utopia: The Then and There of Queer Futurity. New York University Press, 2019.

Paz, Octavio. The Labyrinth of Solitude. Translated by Lysander Kemp, Grove Press, 1994.

Pérez, Emma. The Decolonial Imaginary: Writing Chicanas into History. Indiana University Press, 1999.

Plascencia, Salvador. The People of Paper. Mariner Books, 2006.

Quayson, Ato. Postcolonialism: Theory, Practice or Process? Polity Press, 2005.

Ricoeur, Paul. "Existence and Hermeneutics." The Conflict of Interpretations: Essays in Hermeneutics. Ed Don Ihde \& transl. Kathleen McLaughlin, Northwestern University Press, 1988. 3-24.

Ricoeur, Paul. Figuring the Sacred: Religion, Narrative, and Imagination. Ed. Mark I. Wallace \& Transl. David Pellauer, Fortress Press, 1995.

Ricoevr, Paul. Hermeneutics and the Human Sciences: Essays on Language, Action, and Interpretation. Ed. \& transl. John B. Thompson, Cambridge University Press, 2016.

Ricoeve, Paul. "The Metaphorical Process as Cognition, Imagination, and Feeling.” Critical Inquiry 5/1 (1978): 143-159.

Sandoval, Chela. Methodology of the Oppressed. University of Minnesota Press, 2008. 
SEYMour, Nicole. Strange Natures: Futurity, Empathy, and the Queer Ecological Imagination. University of Illinois Press, 2013.

ShкLovsky, Viktor. “Art as Device.” Viktor Shklovsky: a Reader. Ed. \& transl. Alexandra Berlina, Bloomsbury, 2017. 73-96.

The New American Bible: Revised Edition. United States Conference of Catholic Bishops, 2010.

Thomas, Piri. Down These Mean Streets. Vintage Books, 1997.

VÁzquez, David J. Triangulations: Narrative Strategies for Navigating Latino Identity. University of Minnesota Press, 2011.

Zipes, Jack. Ernst Bloch: The Pugnacious Philosopher of Hope. Springer, 2019.

ŽıžEK, Slavoj. The Plague of Fantasies. Verso, 2009. 